\title{
FAKTOR YANG BERHUBUNGAN DENGAN TINGKAT PENGETAHUAN PEGAWAI MENGENAI KESELAMATAN PASIEN PADA PUSKESMAS RAWAT INAP KOTA DENPASAR
}

\author{
Ni Nyoman Intan Widya Sari, Putu Ayu Indrayathi* \\ Program Studi Sarjana Kesehatan Masyarakat Universitas Udayana \\ Jalan P.B. Sudirman, Denpasar, Bali, 80232
}

\begin{abstract}
ABSTRAK
Keselamatan pasien merupakan suatu sistem yang membuat asuhan pasien menjadi lebih aman. Dengan adanya pandemi COVID-19, membuat fasilitas pelayanan kesehatan memiliki tantangan dalam memastikan dan meningkatkan keselamatan pasien. Penelitian ini bertujuan untuk mengetahui faktor-faktor yang berhubungan dengan tingkat pengetahuan pegawai puskesmas mengenai keselamatan pasien pada puskesmas rawat inap di Kota Denpasar. Desain penelitian yang digunakan adalah penelitian kuantitatif deskriptif dengan rancangan cross-sectional study. Sampel dari penelitian ini yaitu seluruh pegawai puskesmas medis dan non medis yang bekerja di puskesmas rawat inap Kota Denpasar yaitu 124 responden, teknik pengambilan sampel menggunakan metode total sampling. Hasil univariat dengan menggunakan uji beda proporsi menunjukkan karakteristik pegawai di puskesmas tidak terdapat perbedaan yang bermakna. Hasil bivariat dengan menggunakan Simple Logistic Regression menunjukkan tidak ada hubungan antara variabel umur, jenis kelamin, pengalaman kerja, tingkat pendidikan, pelatihan terhadap tingkat pengetahuan. Hasil multivariat menggunakan Binary Logistic Regression menunjukkan bahwa tidak terdapat perbedaan bermakna (Ho diterima). Memberikan pelatihan kepada pegawai puskesmas, mengevaluasi mutu pelayanan, mengembangkan standar kinerja, membentuk tim keselamatan pasien dan mengoptimalkan perannya dan memperbaiki sistem pencatatan, pelaporan serta penyimpanan data.
\end{abstract}

Kata kunci: Pengetahuan, Keselamatan pasien, Puskesmas, Pegawai, Puskesmas Rawat Inap

\begin{abstract}
Patient safety is a system that makes patient care safer. With the COVID-19 pandemic, healthcare facilities have challenges in ensuring and improving patient safety. This research aims to investigate the factors related to the level of knowledge of primary health care (Puskesmas) officers on the safety of patients at an Inpatient Health Center in Denpasar City. It used descriptive quantitative research design with a cross-sectional study draft. Samples from this study are all employees of medical and non-medical health centers working in inpatient health centers denpasar, namely 124 respondents, sampling techniques using the total sampling method. Univariate results using different tests of proportions showed the characteristics of employees in puskesmas there was no meaningful difference. Bivariate results using Simple Logistic Regression showed no relationship between age, gender, work experience, education level, training to knowledge level. Multivariate results using Binary Logistic Regression show that there is no significant difference (Ho is accepted). Provide training to puskesmas employees, evaluate the quality of services, develop performance standards, form patient safety teams and optimize their role and improve the recording, reporting and data storage systems.
\end{abstract}

Keywords: Knowledge, Patient Safety, Primary Health Care , Officers, Inpatient Health Center

\section{PENDAHULUAN}

Keselamatan pasien merupakan salah satu hak yang dimiliki oleh setiap pasien dan juga merupakan salah satu komponen yang dinilai penting dalam menentukan kualitas dan akreditasi dari suatu institusi pelayanan kesehatan (Fatimah et al., 2016). Keselamatan Pasien didefinisikan sebagai suatu sistem dari institusi pelayanan kesehatan dalam membuat asuhan pasien menjadi lebih aman, dan dapat mencegah terjadinya cedera yang disebabkan oleh kesalahan akibat melakukan tindakan medis atau tidak mengambil tindakan medis yang seharusnya diberikan pada saat pemberian pelayanan kesehatan kepada pasien (Brahmana, Wahyudi dan Hilfi, 2018). 
Secara eksplisit, aspek keselamatan pasien terdapat pada Permenkes No 75 tahun 2014 tentang puskesmas dan Permenkes No 11 tahun 2017 tentang Keselamatan Pasien yang kemudian dimasukkan kedalam Standar Akreditasi Puskesmas (sebagai bagian dari Standar Akreditasi Fasilitas Pelayanan Tingkat Pertama disamping Dokter Praktik Mandiri dan Klinik) (Nuryati, 2017). Perkembangan isu keselamatan pasien di puskesmas tidak sedinamis yang terdapat di rumah sakit, padahal jumlah rumah sakit di Indonesia tidak sebanding dengan banyaknya jumlah puskesmas yang ada di Indonesia. Dilihat dari jumlah rumah sakit di Indonesia pada tahun 2015 berjumlah 2.490 dan pada tahun 2016 berjumlah 2.623. Hal tersebut tidak sebanding dengan jumlah puskesmas yang ada di Indonesiayang melebihi jumlah rumah sakit yaitu pada tahun 2015 sebanyak 9.754 dan pada tahun 2016 sebanyak 9.767 (Islami, Arso and Lestantyo, 2018).

Mengingat pentingnya aspek keselamatan pasien untuk senantiasa diperhatikan dan ditingkatkan pada fasilitas pelayanan kesehatan, tentu insiden keselamatan pasien harus diminimalisir agar tidak terjadi pada saat pemberian layanan kesehatan, akan tetapi pada kenyataannya apabila ditinjau dari berbagai insiden keselamatan pasien, dapat disimpulkan bahwa dalam pelaksanaan keselamatan pasien masih kurang optimal, baik insiden yang terjadi secara global maupun secara nasional (Araujo et al., 2019).

Insiden keselamatan pasien di dunia, berdasarkan dari laporan Department Health and Human Service-USA, ditemukan bahwa 13,5\% dari Hospitalized Mediacare Beneficiaries mengalami kejadian tidak diharapkan saat dirawat dirumah sakit dan 1,5\% yang mengalami kejadian sampai dengan kematian (Kerfoot et al., 2007).

Insiden keselamatan pasien di Indonesia dalam rentang waktu 2006 2011 Komite Keselamatan Pasien Rumah Sakit (KKPRS) didapatkan bahwa KTD terbanyak jenisnya berjumlah 69 kejadian (43,67\%) Kejadian Nyaris Cedera (KNC) pada pasien rawat inap, diantaranya yaitu salah pemberian obat $(29,2 \%)$, pasien jatuh $(23,4 \%)$, batal operasi $(14,3 \%)$, dan kesalahan identifikasi pasien (11\%). Insiden keselamatan pasien di Provinsi Bali sebesar 1,4\% dari 145 insiden yang terjadi (Dinkes, 2019).

Berdasarkan studi pendahuluan yang dilakukan pada lokasi penelitian, berdasarkan laporan yang ada tercatat terdapat beberapa insiden keselamatan pasien di Puskesmas IV Denpasar Selatan diantaranya insiden KNC yang terjadi pada tanggal 12 Desember 2018, kemudian insiden KNC yang terjadi kembali pada tanggal 13 Maret 2019 dan insiden KNC yang terjadi lainnya terjadi pada tanggal 18 Maret 2019.

Berdasarkan data yang telah di rekap di puskesmas, pada Puskesmas I Denpasar Timur tercatat pernah mengalami insiden keselamatan pasien pada tahun 2016-2018. Pada bulan JanuariMaret 2016, tercatat telah terjadi Kejadian Tidak Cedera (KTC). Insiden keselamatan pasien yang terjadi pada bulan April-Juni 2016, tercatat terdapat Kejadian Potensial Cedera (KPC) sejumlah 11 insiden. Pada bulan Juli-September 2021 tercatat insiden 
Kejadian Tidak Cedera (KTC) sejumlah 1 insiden, Kejadian Potensial Cedera (KPC) sejumlah 1 insiden. Pada bulan OktoberDesember 2021 telah terjadi Kejadian Potensial Cedera (KPC) yang berjumlah 1 insiden. Insiden keselamatan pasien lainnya yang tercatat di Puskesmas I Denpasar Timur diantaranya adalah pada bulan Januari-Maret 2019 yaitu Kejadian Nyaris Cedera (KNC) sejumlah 1 insiden.

Berdasarkan studi pendahuluan yang dilakukan melalui wawancara dapat diketahui bahwa pada Puskesmas IV Denpasar Selatan telah membentuk tim KP, sedangkan pada Puskesmas I Denpasar Timur belum dibentuk tim KP, masih terdapatnya double job dikedua puskesmaskan dikarenakan sibuknya pelayanan dan responden dikedua puskesmas tersebut menyatakan masih kurangnya pelatihan. Menurut Henriksen,K., et al (2008) menyatakan terdapat beberapa faktor yang berkontribusi terhadap terjadinya insiden keselamatan pasien, salah satunya yaitu faktor manusia yang mencakup pengetahuan manusia itu sendiri. Sehingga, peneliti tertarik untuk mengukur dan mengetahui faktor-faktor yang berhubungan dengan tingkat pengetahuan pegawai puskesmas mengenai keselamatan pasien dengan membandingkan sekaligus pada puskesmas Rawat Inap di Kota Denpasar yaitu Puskesmas IV Denpasar Selatan dengan akreditasi paripurna dengan Puskesmas I Denpasar Timur dengan akreditasi utama (Misnaniarti and Destari, 2018).

\section{METODE PENELITIAN}

Penelitian ini adalah penelitian deskriptif kuantitatif dengan pendekatan cross sectional study. Variabel independennya adalah variabel usia, jenis kelamin, tingkat pendidikan, pengalaman kerja, informasi dan pelatihan. Sedangkan variabel dependen adalah tingkat pengetahuan pegawai puskesmas mengenai keselamatan pasien. Teknik sampling yang digunakan yaitu Total Sampling dengan sampel pegawai puskesmas yang bekerja di Puskesmas IV Denpasar Selatan dan Puskesmas I Denpasar Timur yang total respondennya adalah 124 orang. Data yang telah dikumpulkan kemudian dianalisis dalam tiga tahap yaitu analisis deskriptif, uji beda proporsi dan regresi logistik menggunakan software STATA versi 12 For Windows. Penelitian ini telah mendapatkan kelaikan etik dari Komisi Etik Penelitian Litbang FK Unud/Rumah Sakit Umum Pusat Sanglah dengan Nomor: 1565/UN14.2.2.VII.14/LT/2021.

HASIL

Pengumpulan data dilakukan secara offline dengan menggunakan pernyataan positif dan negatif yang diadaptasi dari Permenkes RI No. 11 Tahun 2017. Sebelum penelitian dilakukan, peneliti melakukan uji coba kuesioner pada puskesmas yang memiliki karakteristik yang sama. Puskesmas III Denpasar Utara yang terakreditasi paripurna memiliki kesamaan dengan Puskesmas IV Denpasar Selatan. Sedangkan pada Puskesmas II Denpasar Timur yang terakreditasi utama memiliki kesamaan dengan Puskesmas I Denpasar Timur. 
Tabel 1 menunjukkan gambaran karakteristik demografi responden penelitian di Puskesmas I Denpasar Timur dan Puskesmas IV Denpasar Selatan. Jika dilihat dari variabel usia, rata-rata responden di Puskesmas I Denpasar Timur berusia 33,96 tahun dan sebagian besar tergolong < 35 tahun yaitu sebanyak 36 orang (66,67\%). Sedangkan pada Puskesmas IV Denpasar Selatan, rata-rata responden berusia $\geq 35$ tahun, yaitu sebanyak 45 orang (64,29\%). Pada Puskesmas I Denpasar Timur, sebagian besar responden berjenis kelamin perempuan yaitu sebanyak 46 orang $(85,19 \%)$ dan pada Puskesmas IV Denpasar Selatan, sebagian besar responden berjenis kelamin perempuan yaitu sebanyak 62 orang (88,57\%). Pada Puskesmas I Denpasar Timur, sebagian besar berpendidikan D3 yaitu sebanyak 32 orang (59,26\%). Sedangkan pada Puskesmas IV Denpasar Selatan, sebagian besar berpendidikan S1, yaitu sebanyak 28 orang (40,00\%). Pada Puskesmas I Denpasar Timur, rata-rata sudah bekerja selama 9,42 tahun serta sebagian besar memiliki pengalaman kerja $<9$ tahun, yaitu sebanyak 28 orang (51,85\%). Sedangkan pada Puskesmas IV Denpasar Selatan, rata-rata pengalaman kerja selama 9,23 tahun dan sebagian besar pengalaman kerja $\geq 9$ tahun, yaitu sebanyak 39 orang (55,71\%). Pada Puskesmas I Denpasar Timur maupun Puskesmas IV Denpasar Selatan menyatakan pernah memperoleh informasi mengenai keselamatan pasien. Pada Puskesmas I Denpasar Timur, sebagian besar responden menyatakan tidak pernah, yaitu sebanyak 48 orang (88,09\%). Sedangkan pada Puskesmas IV Denpasar Selatan, sebagian besar responden juga menyatakan tidak pernah, yaitu sebanyak 58 orang (82,86\%). Pada Puskesmas I Denpasar Timur, sebagian besar tergolong baik yaitu sebanyak 35 orang (64,81\%). Sedangkan pada Puskesmas IV Denpasar Selatan, sebagian besar responden juga tergolong baik, yaitu sebanyak 45 orang $(64,29 \%)$. 
Tabel 1. Karakteristik Demografi Responden

Variabel

Puskesmas I Denpasar

Timur

\begin{tabular}{lcccc}
\cline { 2 - 4 } & Jumlah & \% & Jumlah & \% \\
\hline Usia & & & & \\
Mean (SD) & $33,96(8,10)$ & & $38,06(8,76)$ & \\
Min - Max & $23-52$ & & $24-56$ & \\
$<35$ tahun & 36 & 66,67 & 25 & 35,71 \\
$\geq 35$ tahun & 18 & 33,33 & 45 & 64,29
\end{tabular}

Jenis kelamin

Perempuan

46

85,19

62

88,57

Laki-laki

8

14,81

8

11,43

\section{Pendidikan}

SMA

D3

S1

Profesi

\section{Pengalaman Kerja}

$$
\begin{aligned}
& \text { Mean (SD) } \\
& \text { Min - Max } \\
& <9 \text { tahun } \\
& \geq 9 \text { tahun }
\end{aligned}
$$

\section{Informasi}

Tidak pernah

Pernah

\section{Pelatihan}

Tidak pernah

Pernah

\section{Pengetahuan}

$\begin{array}{lc}\text { Mean (SD) } & 35,05(3,87) \\ \text { Median (Min - Max) } & 36(19-40) \\ \text { Kurang } & 19 \\ \text { Baik } & 35\end{array}$

Tabel 2 dibawah menunjukkan gambaran tingkat pengetahuan pegawai puskesmas mengenai keselamatan pasien. Tingkat pengetahuan tersebut diukur menggunakan kuesioner dengan jumlah 40 pernyataan yang meliputi definisi

$\begin{array}{ccc}0,00 & 5 & 7,14 \\ 59,26 & 22 & 31,43 \\ 14,81 & 28 & 40,00 \\ 25,93 & 15 & 21,43\end{array}$

$$
\begin{gathered}
9,23(6,42) \\
0,5-34
\end{gathered}
$$

51,85

31

44,29

48,15

39

55,71

0,00

100,00

0

0,00

70

100,00

88,09

58

82,86

11,11

12

17,14
$35,43(2,94)$

2,94 (24-40)

35,19

25

35,71

64,81

45

64,29 keselamatan pasien, sasaran keselamatan pasien (identifikasi pasien, meningkatkan komunikasi yang efektif, meningkatkan keamanan obat-obatan yang perlu di waspadai, mengurangi risiko infeksi akibat perawatan kesehatan). 
Hasil analisa menunjukkan bahwa didapatkan pada Puskesmas I Denpasar Timur memiliki rata-rata $35,05(\mathrm{SD}=3,87)$ dengan 19 responden $(35,19 \%)$ memiliki pengetahuan kurang baik dan sebanyak 35 responden $(64,81 \%)$ memiliki pengetahuan baik. Pada Puskesmas IV Denpasar Selatan, nilai rata-rata 35,43 $(\mathrm{SD}=2,94)$ dengan 25 responden $(35,71 \%)$ memiliki pengetahuan kurang baik dan sebanyak 45 responden (64,29\%) memiliki pengetahuan baik.

Tabel 2. Gambaran Tingkat Pengetahuan Responden

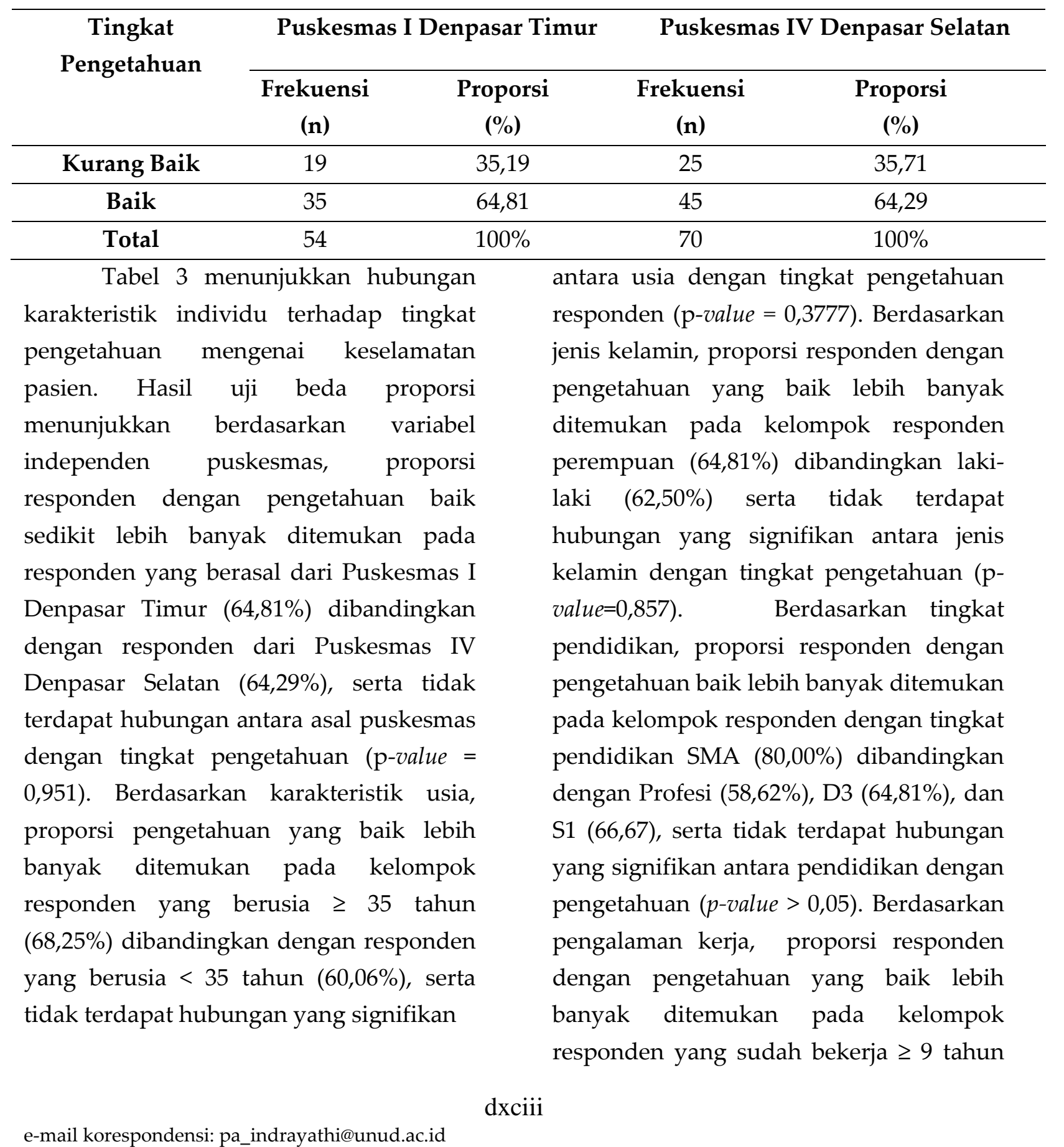


$(69,23 \%)$ dibandingkan dengan responden yang bekerja $<9$ tahun $(59,32 \%)$, serta tidak terdapat hubungan yang signifikan antara lama waktu pengalaman kerja dengan pengetahuan ( $p$-value $=0,251$ ) . Berdasarkan keterpaparan informasi terkait keselamatan pasien, semua responden yang menyatakan pernah mendapatkan informasi memiliki pengetahuan yang baik. Berdasarkan riwayat pelatihan terkait dengan keselamatan pasien, proporsi responden dengan pengetahuan yang baik lebih banyak ditemukan pada kelompok responden yang tidak pernah $(66,04 \%)$ dibandingkan dengan responden yang pernah $(55,56 \%)$, serta tidak terdapat hubungan yang signifikan antara pelatihan dengan pengetahuan ( $p$-value $=$ $0,392 \%)$.

Tabel 3. Hubungan Karakteristik Individu dengan Tingkat Pengetahuan

\begin{tabular}{|c|c|c|c|c|}
\hline \multirow[b]{2}{*}{ Variabel } & \multicolumn{2}{|c|}{ Pengetahuan } & \multirow[b]{2}{*}{ OR $(95 \%$ CI $)$} & \multirow[b]{2}{*}{$p$-value } \\
\hline & $\begin{array}{c}\text { Kurang } \\
\text { f }(\%)\end{array}$ & $\begin{array}{c}\text { Baik } \\
\text { f }(\%)\end{array}$ & & \\
\hline \multicolumn{5}{|l|}{ Puskesmas } \\
\hline Pus. I Denpasar Timur & $19(35,19)$ & $35(64,81)$ & Ref & \\
\hline Pus. IV Denpasar Selatan & $25(35,71)$ & $45(64,29)$ & $0,98(0,46-2,05)$ & 0,951 \\
\hline \multicolumn{5}{|l|}{ Usia } \\
\hline$<35$ tahun & $24(39,34)$ & $37(60,06)$ & Ref & \\
\hline$\geq 35$ tahun & $20(31,75)$ & $42(68,25)$ & $1,39(0,67-2,91)$ & 0,377 \\
\hline \multicolumn{5}{|l|}{ Jenis kelamin } \\
\hline Perempuan & $38(35,19)$ & $70(64,81)$ & Ref & \\
\hline Laki-laki & $6(37,50)$ & $10(62,50)$ & $0,90(0,31-2,68)$ & 0,857 \\
\hline \multicolumn{5}{|l|}{ Pendidikan } \\
\hline SMA & $1(20,00)$ & $4(80,00)$ & Ref & \\
\hline D3 & $19(35,19)$ & $35(64,81)$ & $0,46(0,5-4,42)$ & 0,502 \\
\hline S1 & $12(33,33)$ & $24(66,67)$ & $0,50(0,05-4,98)$ & 0,554 \\
\hline Profesi & $12(41,38)$ & $17(58,62)$ & $0,35(0,04-3,57)$ & 0,379 \\
\hline \multicolumn{5}{|l|}{ Pengalaman kerja } \\
\hline$<9$ tahun & $24(40,68)$ & $35(59,32)$ & Ref & \\
\hline$\geq 9$ tahun & $20(30,11)$ & $45(69,23)$ & $1,54(0,73-3,23)$ & 0,251 \\
\hline \multicolumn{5}{|l|}{ Informasi } \\
\hline Tidak pernah & $0(0,00)$ & $0(0,00)$ & Ref & \\
\hline Pernah & $44(35,48)$ & $80(64,52)$ & 1 & - \\
\hline \multicolumn{5}{|l|}{ Pelatihan } \\
\hline Tidak pernah & $36(33,96)$ & $70(66,04)$ & Ref & \\
\hline Pernah & $8(44,44)$ & $10(55,56)$ & $0,64(1,30-2,90)$ & 0,392 \\
\hline
\end{tabular}

Tabel 4 menunjukkan hubungan antara karakteristik individu dengan tingkat pengetahuan dari responden menggunakan Binary Logstic Regression.
Hasil analisis menunjukkan bahwa responden yang berasal dari Puskesmas IV Denpasar Selatan lebih kecil kemungkinannya untuk berpengetahuan 
baik sebesar $22 \%$ dibandingkan dengan responden yang berasal dari Puskesmas I Denpasar Timur, serta tidak terdapat hubungan yang signifikan antara asal puskesmas dengan pengetahuan responden $(\mathrm{OR}=0,78)$. Berdasarkan karakteristik usia, responden yang berusia $\geq 35$ tahun cenderung 1,82 kali untuk memiliki pengetahuan baik dibandingkan dengan responden yang berusia $<35$ tahun, serta tidak terdapat hubungan yang signifikan antara usia dengan pengetahuan responden $(\mathrm{OR}=1,82)$. Berdasarkan jenis kelamin, responden laki-laki lebih kecil kemungkinan memiliki pengetahuan baik sebesar 17\% dibandingkan dengan responden perempuan, serta tidak terdapat hubungan yang signifikan antara jenis kelamin dengan pengetahuan responden $(\mathrm{OR}=0,83)$. Berdasarkan tingkat pendidikan, responden dengan tingkat pendidikan D3 lebih kecil kemungkinannya untuk memiliki pengetahuan baik sebesar 54\% dibandingkan dengan responden dengan tingkat pendidikan SMA, serta tidak terdapat hubungan yang signifikan antara tingkat pendidikan D3 dengan pengetahuan responden $(\mathrm{OR}=0,46)$. Responden dengan tingkat pendidikan S1 lebih kecil kemungkinannya memiliki pengetahuan yang baik sebesar 57\% dibandingkan dengan tingkat pendidikan SMA, serta tidak terdapat hubungan yang signifikan antara pendidikan S1 dengan pengetahuan $(\mathrm{OR}=0,43)$. Selain itu, repsonden yang berpendidikan profesi juga kecil kemungkinannya memiliki pengetahuan baik sebesar 0,69\% dibandingkan dengan responden berpendidikan SMA, serta tidak terdapat hubungan yang signifikan antara pendidikan profesi dengan pengetahuan responden ( $\mathrm{OR}=0,31)$. Responden dengan pengalaman kerja $\geq 9$ tahun juga kecil kemungkinannya memiliki pengetahuan baik sebesar 3\% dibandingkan dengan responden yang memiliki pengalaman kerja $<9$ tahun, tidak terdapat hubungan yang signifikan antara lama pengalaman bekerja dengan pengetahuan responden $(\mathrm{OR}=0,97)$. Berdasarkan pelatihan, responden yang pernah memperoleh pelatihan lebih kecil kemungkinan memiliki pengetahuan yang baik sebesar $22 \%$ dibandingkan dengan responden yang tidak memperoleh pelatihan tentang keselamatan pasien, serta tidak terdapat hubungan yang signifikan antara pengalaman pelatihan dengan pengetahuan responden $(\mathrm{OR}=0,83)$. 
Tabel 4. Hubungan Karakteristik Individu dengan Tingkat Pengetahuan

\begin{tabular}{lccc}
\hline \multicolumn{1}{c}{ Variabel } & OR & $\mathbf{9 5 \%}$ CI & p-valu \\
\hline $\begin{array}{l}\text { Puskesmas } \\
\quad \text { Pus. I Denpasar Timur }\end{array}$ & Ref & & \\
$\quad$ Pus. IV Denpasar Selatan & 0,78 & $0,33-1,84$ & 0,575 \\
Usia & & & \\
$\quad$ <35 tahun & Ref & & 0,285 \\
$\quad \geq 35$ tahun & 1,82 & $0,61-5,44$ & \\
Jenis kelamin & & & \\
$\quad$ Perempuan & Ref & & \\
$\quad$ Laki-laki & 0,83 & 0,784 \\
Pendidikan & & & \\
SMA & Ref & & \\
D3 & 0,46 & $0,04-5,21$ & 0,532 \\
S1 & 0,43 & $0,04-4,90$ & 0,497 \\
Profesi & 0,31 & $0,03-3,64$ & 0,350
\end{tabular}

Pengalaman kerja

$<9$ tahun

Ref

$\geq 9$ tahun $\quad 0,97$

$0,90-1,05$

0,473

\section{Informasi}

Tidak pernah

Ref

Pernah

1

Pelatihan

Tidak pernah

Ref

Pernah

0,78

$0,27-2,26$

0,652

Berdasarkan tabel 5, untuk

mengetahui perbedaan tingkat pengetahuan responden pada Puskesmas I Denpasar Timur dan Puskesmas IV Denpasar Selatan, peneliti menggunakan Binary Logistic Regression. Dapat diketahui bahwa variabel puskesmas tidak terdapat perbedaan yang bermakna antara puskesmas dengan tingkat pengetahuan ( $\mathrm{p}$-value $=0,951)$. Pada variabel usia, dapat diketahui bahwa tidak terdapat perbedaan yang bermakna antara variabel usia dengan tingkat pengetahuan ( $\mathrm{p}$-value = 0,377). Pada variabel jenis kelamin, dapat diketahui bahwa tidak terdapat perbedaan yang bermakna antara variabel jenis kelamin dengan tingkat pengetahuan ( $\mathrm{p}$ value $=0,857)$. Pada variabel Pendidikan, dapat diketahui bahwa tidak terdapat perbedaan yang bermakna antara variabel tingkat pendidikan dengan tingkat pengetahuan ( $\mathrm{p}$-value $\geq 0,05$ ). Pada variabel pengalaman kerja, dapat diketahui bahwa tidak terdapat hubungan yang bermakna antara pengalaman kerja dengan tingkat pengetahuan ( $\mathrm{p}$-value = 0,251). Pada variabel Informasi, dapat diketahui bahwa tidak terdapat hubungan yang bermakna antara informasi dengan tingkat pengetahuan. Pada variabel pelatihan, tidak terdapat hubungan yang 
bermakna dengan tingkat pengetahuan ( $\mathrm{p}-$ value $=0,392$ ).

Berdasarkan hasil penelitian, dapat diketahui bahwa pada Puskesmas IV Denpasar Selatan, responden dengan tingkat pengetahuan kategori baik sejumlah 45 responden (64,29\%) dan responden dengan tingkat pengetahuan kategori kurang baik sejumlah 25 responden $(35,71 \%)$ dengan nilai rata-rata 35,43. Pada puskesmas I Denpasar Timur, responden dengan tingkat pengetahuan kategori baik sejumlah 35 responden $(64,81 \%)$ dan tingkat pengetahuan kategori kurang baik sejumlah 19 responden $(35,19 \%)$ dengan nilai rata-rata 35,05 .

Tabel 5. Perbandingan Karakteristik Individu terhadap Tingkat Pengetahuan Responden Pada Puskesmas Rawat Inap

Variabel OR $(95 \% \mathrm{CI}) \quad p$-value

\section{Puskesmas}

Pus. I Denpasar Timur

Ref

Pus. IV Denpasar Selatan

$0,98(0,46-2,05)$

0,951

Usia

$<35$ tahun

Ref

$\geq 35$ tahun

$1,39(0,67-2,91)$

0,377

Jenis kelamin

Perempuan

Ref

Laki-laki

$0,90(0,31-2,68)$

0,857

Pendidikan

SMA

Ref

D3

$0,46(0,5-4,42)$

0,502

S1

$0,50(0,05-4,98)$

0,554

Profesi

$0,35(0,04-3,57)$

0,379

\section{Pengalaman kerja}

$<9$ tahun

Ref

$\geq 9$ tahun

$1,54(0,73-3,23)$

0,251

Informasi

Tidak pernah

Ref

Pernah

Pelatihan

Tidak pernah

Ref

Pernah 


\section{DISKUSI}

\section{Tingkat Pengetahuan Responden}

Berdasarkan tingkat pengetahuan responden, pada Puskesmas I Denpasar Timur terdapat responden dengan tingkat pengetahuan baik sebanyak 35 orang $(64,81 \%)$ dan responden dengan tingkat pengetahuan yang kurang baik sebanyak 19 orang (35,19\%). Sedangkan pada Puskesmas IV Denpasar Selatan, responden dengan tingkat pengetahuan baik sebanyak 45 orang $(64,29 \%)$ dan responden dengan tingkat pengetahuan kurang baik sebanyak 25 orang $(35,71 \%)$.

\section{Hubungan Karakteristik Individu dengan Tingkat Pengetahuan}

Berdasarkan analisis yang dilakukan menggunakan Binary Logistic Regression. Pada variabel puskesmas, tidak terdapat hubungan yang signifikan antara asal puskesmas dengan pengetahuan responden ( $p$-value $=0,951$ ). Pada variabel usia, tidak terdapat hubungan yang signifikan antara usia dengan pengetahuan responden $(p$-value $=$ 0,377). Pada variabel jenis kelamin, tidak terdapat hubungan yang signifikan antara jenis kelamin dengan pengetahuan responden $(p$-value $=0,857)$. Pada variabel tingkat pendidikan, tidak terdapat hubungan yang signifikan antara pendidikan dengan pengetahuan ( $p$-value $>0,05)$. Pada variabel pengalaman kerja, tidak terdapat hubungan yang signifikan antara lama waktu pengalaman kerja dengan pengetahuan ( $p$-value $=0,251$ ). Pada variabel informasi mengenai keselamatan pasien, semua responden yang menyatakan pernah mendapatkan informasi memiliki pengetahuan yang baik. Pada variabel pelatihan mengenai keselamatan pasien, tidak terdapat hubungan yang signifikan antara pelatihan dengan pengetahuan $(p$-value $=$ 0,392).

\section{Hasil Analisis Multivariat}

Hasil analisis menunjukkan bahwa responden yang berasal dari Puskesmas IV Denpasar Selatan lebih kecil kemungkinannya untuk berpengetahuan baik sebesar 22\% dibandingkan dengan responden yang berasal dari Puskesmas I Denpasar Timur. Jika dilihat dari karakteristik usia, responden yang berusia $\geq 35$ tahun cenderung 1,82 kali untuk memiliki pengetahuan baik dibandingkan dengan responden yang berusia $<35$ tahun. Jika dilihat dari jenis kelamin, responden laki-laki lebih kecil kemungkinan memiliki pengetahuan baik sebesar $17 \%$ dibandingkan dengan responden perempuan. Jika dilihat dari pendidikan SMA, responden dengan pendidikan D3 lebih kecil kemungkinannya untuk memiliki pengetahuan baik sebesar 54\% dibandingkan dengan responden SMA, serta tidak terdapat hubungan yang signifikan antara pendidikan D3 dengan pengetahuan responden. Responden dengan pendidikan S1 lebih kecil kemungkinannya memiliki pengetahuan yang baik sebesar 57\% dibandingkan dengan pendidikan SMA, serta tidak terdapat hubungan yang signifikan antara pendidikan S1 dengan pengetahuan. Selain itu, responden yang berpendidikan profesi juga kecil kemungkinannya memiliki pengetahuan baik sebesar 0,69\% dibandingkan dengan responden berpendidikan SMA, serta tidak terdapat hubungan yang signifikan antara 
pendidikan profesi dengan pengetahuan responden. Responden dengan pengalaman kerja lebih dari atau sama dengan 9 tahun juga kecil keumngkinannya memiliki pengetahuan baik sebesar 3\% dibandingkan dengan responden yang memiliki pengalaman kerja kurang dari 9 tahun. Selain itu, responden yang mendapatkan pelatihan juga lebih kecil kemungkinannya memiliki pengetahuan yang baik sebesar $22 \%$ dibandingkan dengan responden yang tidak memperoleh pelatihan tentang keselamatan pasien.

\section{Perbandingan Tingkat Pengetahuan} Karakteristik Individu terhadap Tingkat Pengetahuan Responden Pada Puskesmas Rawat Inap

Dapat diketahui bahwa variabel puskesmas tidak terdapat perbedaan yang bermakna antara puskesmas dengan tingkat pengetahuan ( $\mathrm{p}$-value $=0,951)$. Pada variabel usia, dapat diketahui bahwa tidak terdapat perbedaan yang bermakna antara variabel usia dengan tingkat pengetahuan ( $\mathrm{p}$-value $=0,377$ ). Pada variabel jenis kelamin, dapat diketahui bahwa tidak terdapat perbedaan yang bermakna antara variabel jenis kelamin dengan tingkat pengetahuan $(\mathrm{p}$-value $=$ 0,857). Pada variabel Pendidikan, dapat diketahui bahwa tidak terdapat perbedaan yang bermakna antara variabel tingkat pendidikan dengan tingkat pengetahuan ( $\mathrm{p}$-value $\geq 0,05$ ). Pada variabel pengalaman kerja, dapat diketahui bahwa tidak terdapat hubungan yang bermakna antara pengalaman kerja dengan tingkat pengetahuan ( $\mathrm{p}$-value $=0,251$ ). Pada variabel Informasi, dapat diketahui bahwa tidak terdapat hubungan yang bermakna antara informasi dengan tingkat pengetahuan. Pada variabel pelatihan, tidak terdapat hubungan yang bermakna dengan tingkat pengetahuan $(\mathrm{p}$-value $=$ $0,392)$.

\section{SIMPULAN}

Berdasarkan hasil penelitian yang dilakukan pada puskesmas rawat inap di Kota Denpasar, dapat disimpulkan bahwa tingkat pengetahuan pegawai mengenai keselamatan pasien di kedua puskesmas dalam kategori baik, pada Puskesmas I Denpasar Timur memiliki tingkat pengetahuan baik sebanyak 35 orang $(64,81 \%)$ dan tingkat pengetahuan kurang baik sebanyak 19 orang $(35,19 \%)$.

Sedangkan pada Puskesmas IV Denpasar Selatan memiliki tingkat pengetahuan baik sebanyak 45 orang (64,29\%) dan tingkat pengetahuan kurang baik sebanyak 25 orang $(35,71 \%)$. Tidak terdapat hubungan antara karakteristik individu dengan tingkat pengetahuan. Berdasarkan analisis menggunakan Binary Logistic Regression untuk melihat perbedaan tingkat pengetahuan di kedua puskesmas rawat inap, dapat diketahui bahwa tidak terdapat perbedaan yang bermakna ( $p$-value $=0,560$ ).

SARAN

Bagi puskesmas, lebih memperkenalkan kembali keselamatan pasien kepada pegawai puskesmas melalui sosialisasi mengenai keselamatan pasien yang bisa diberikan melalui poster, media informasi lainnya, sosialisasi berupa pelatihan mengenai keselamatan pasien terutama mengenai sasaran keselamatan pasien pada aspek keamanan obat-obatan yang harus diwaspadai dikarenakan masih terdapat 
beberapa pegawai belum mengetahui secara pasti obat-obatan apa saja yang harus diwaspadai dalam melakukan pelayanan kesehatan.

Pihak manajemen Puskesmas IV Denpasar Selatan hendaknya mengawasi dan memastikan bahwa tim keselamatan pasien yang dibentuk di puskesmas telah menjalankan tugas secara optimal dan mengarahkan apabila terjadi kendala atau hambatan dalam menyelesaikan tugas dan pihak manajemen Puskesmas I Denpasar Timur sebaiknya mengupayakan membentuk tim keselamatan pasien yang anggotanya diambil dari masing-masing unit pelayanan di puskesmas untuk lebih mempermudah dalam pendelegasian tugas serta mempermudah dalam menyebarluaskan informasi mengenai keselamatan pasien.

Pihak manajemen Puskesmas IV Denpasar Selatan diharapkan meningkatkan prosedur dan standar keselamatan pasien untuk dapat mempertahankan mutu pelayanan yang baik, pada Puskesmas I Denpasar Timur dapat memperbaiki sistem pencatatan, pelaporan dan penyimpanan data insiden keselamatan pasien di puskesmas, dikarenakan data keselamatan pasien merupakan komponen penting bagi puskesmas dalam mengevaluasi mutu pelayanannya dan dalam mempertimbangkan keputusan yang dapat diambil terkait insiden yang terjadi.

Bagi peneliti selanjutnya, Diharapkan melakukan penelitian dengan melakukan wawancara langsung kepada responden untuk mendapatkan hasil yang lebih sesuai.

\section{UCAPAN TERIMAKASIH}

Ucapan terima kasih penulis tujukkan kepada seluruh responden yang telah berpartisipasi pada penelitian ini, serta kepada dosen pembimbing dan penguji yang senantiasa memberi masukan terhadap penyelesaian dan penyempurnaan penelitian ini.

\section{DAFTAR PUSTAKA}

Araujo, C. De, C. Anugrahini, Dan D. T. Mau. (2019).Gambaran Tingkat Pengetahuan Perawat dalam Mengidentifikasi Keselamatan Pasien di IGD RSUD Mgr Gabriel Manek, Svd Atambua Nusa Tenggara Timur. Universitas Timor Kampus Atambua. 8(1):213.

Brahmana, R. P., Wahyudi, K. and Hilfi, L. (2018). Perspektif Tenaga Kesehatan: Budaya Keselamatan Pasien pada Puskesmas PONED di Kota Bandung, Health Workers Perspective : Patient Safety Culture in Puskesmas PONED in Bandung City. Jurnal Sistem Kesehatan, VOLUME 3 NOMOR 3 MARET TAHUN 2018, 3, pp. 116-121.

Dinas Kesehatan Kota Denpasar. (2019). Profil Dinas Kesehatan Kota Denpasar Tahun 2019. Available at: https://dinkes.denpasarkota.go.id/ uploads/download/download_192 207090713_ProfilDinasKesehatanK otaDenpasar.pdf (Accessed: 15 Januari 2021)

Fatimah, F. S., \& Rosa, E. M. (2016). Efektivitas Pelatihan patient safety; komunikasi s-bar pada perawat dalam menurunkan kesalahan pemberian obat injeksi 
di Rumah Sakit PKU Muhammadiyah Yogyakarta Unit II. Jurnal Ners dan Kebidanan Indonesia, 2(1), 32-41.

Henriksen, K., Dayton, E., Keyes, M. ., Carayon, P., \& Hughes, R. (2008). Chapter 5.Understanding Adverse Events: A human Factors Framework. In AHRQ Publication.

Islami, K., Arso, S. P. and Lestantyo, D. (2018). Analisis Pelaksanaan Program Keselamatan Pasien Puskesmas Mangkang, Kota Semarang. Jurnal Kesehatan Masyarakat (e-Journal), 6(4), pp. 2741.

Kerfoot, B. P., Conlin, P. R., Travison, T., \& McMahon, G. T. (2007). Patient Safety Knowledge and Its Determinants in Medical Trainees. Journal of General Internal Medicine, 22(8), 1150-1154.

Misnaniarti, M. and Destari, P. K. (2018). Aspek Penting Akreditasi Puskesmas dalam Mendukung Implementasi Jaminan Kesehatan Nasional. Jurnal Penelitian dan Pengembangan Pelayanan Kesehatan, 2(1), pp. 10-16. doi: 10.22435/jpppk.v2i1.35.

Nuryati, S. (2017). Evaluasi Implementasi Sistem Manajemen Mutu ISO 9001:2008 di Puskesmas Wilayah Kabupaten Sleman. Jurnal Medicoeticolegal dan Manajemen Rumah Sakit, 6(2), pp. 128-135. doi: 10.18196/jmmr.6137 